\title{
In Memoriam: Pieter Spierenburg (1948-2019)
}

\section{Paul Lawrence}

\section{OpenEdition}

\section{Journals}

Electronic version

URL: https://journals.openedition.org/chs/2519

DOI: 10.4000/chs.2519

ISSN: 1663-4837

\section{Publisher}

Librairie Droz

\section{Printed version}

Date of publication: 18 December 2019

Number of pages: 99

ISSN: 1422-0857

\section{Electronic reference}

Paul Lawrence, "In Memoriam: Pieter Spierenburg (1948-2019)", Crime, Histoire \& Sociétés / Crime,

History \& Societies [Online], vol. 23, n² | 2019, Online since 06 May 2020, connection on 03 April 2022 URL: http://journals.openedition.org/chs/2519 ; DOI: https://doi.org/10.4000/chs.2519

This text was automatically generated on 3 April 2022.

(C) Droz 


\title{
In Memoriam: Pieter Spierenburg (1948-2019)
}

\author{
Paul Lawrence
}

1 The following texts are printed to mark the passing of Pieter Spierenburg. Pieter was a significant pioneer in the field of criminal justice history, a founder member of the International Association for the History of Crime and Criminal Justice, and a longstanding member of the Editorial Board of this journal. What follows consists of two personal reflections on Pieter and his work (written by James Sharpe and Manon van der Heijden), the translation of an interview with Pieter originally published in Dutch, a consideration of the significance of Pieter's work on confinement (written by Falk Bretschneider and originally presented at the European Social Science History

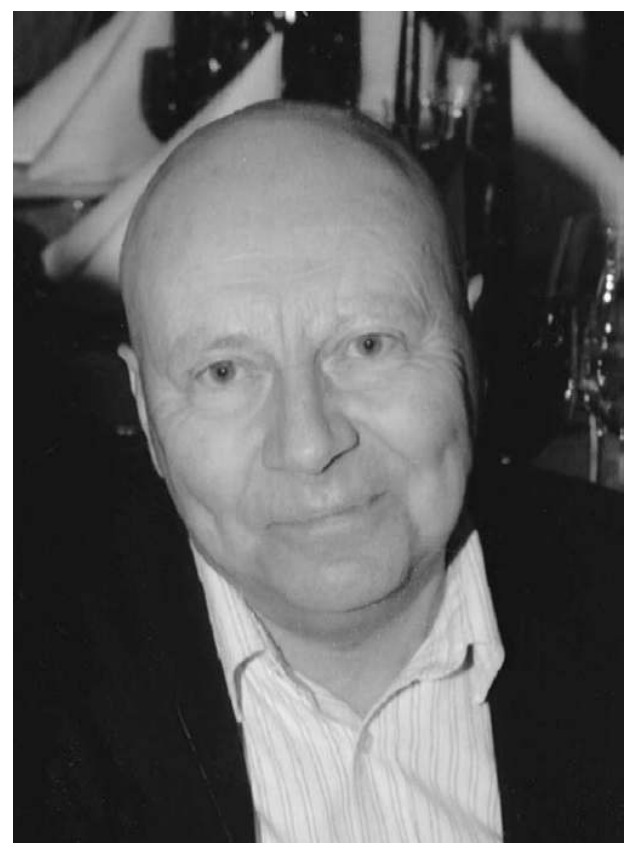
Conference in 2014) and the final book review written by Pieter himself. Pieter Spierenburg was an inspiring historian and a genial colleague who will be sorely missed. 


\section{AUTHOR}

\section{PAUL LAWRENCE}

On behalf of the Editorial Board of Crime, History and Societies

CHS[at]open.ac.uk 